\title{
Building relational capacities from institutional arrangements: lessons based on the construction of Salvador's subway system
}

\section{Victor Bastos Lima ${ }^{1}$ \\ José Carlos Vaz ${ }^{1}$ \\ ${ }^{1}$ Universidade de São Paulo (USP), São Paulo - SP, Brazil}

This article aims to study the construction process of the subway system in the Brazilian cities of Salvador and Lauro de Freitas, investigating the constraints of state agencies to build this subway infrastructure. By examining the structures created to produce this urban infrastructure policy, this paper tries to explain how institutional arrangements of public policies condition state agency, in other words, how they enhance or undermine the formation of policy capacities to deliver subway infrastructure. The qualitative analysis of the data suggests that the design of institutional arrangements and their change influence the availability and mobilization of actors, resources, competences and policy instruments towards the promotion of efficacy and legitimacy in this policy.

Keywords: policy capacity, institutional arrangement, urban infrastructure 


\section{Construindo capacidades relacionais a partir de arranjos institucionais: aprendizados da construção do sistema metroviário de Salvador}

Este artigo tem como objetivo estudar o processo de construção do sistema metroviário nas cidades brasileiras de Salvador e Lauro de Freitas, investigando as limitações das organizações públicas para a construção dessa infraestrutura metroviária. Ao examinar as estruturas criadas para produzir essa política de infraestrutura urbana, este artigo tenta explicar como os arranjos institucionais de políticas públicas condicionam o poder de ação estatal em sua faceta relacional, em outras palavras, como eles aumentam ou prejudicam a formação de capacidades relacionais para entregar infraestrutura metroviária. A análise qualitativa dos dados sugere que o desenho dos arranjos institucionais e suas mudanças influenciam a disponibilidade e mobilização de atores, recursos, competências e instrumentos políticos para a promoção da eficácia e legitimidade dessa política pública.

Palavras-chave: capacidade para políticas públicas, arranjos institucionais, infraestrutura urbana

\section{Construyendo capacidades relacionales a partir de arreglos institucionales: aprendizajes de la construcción del sistema de metro de Salvador}

Este artículo tiene como objetivo estudiar el proceso de construcción del sistema de metro en las ciudades brasileñas de Salvador y Lauro de Freitas, investigando las limitaciones de los organismos públicos para la construcción de esta infraestructura de metro. Al examinar las estructuras creadas para producir esta política de infraestructura urbana, este artículo trata de explicar cómo los arreglos institucionales de políticas públicas condicionan el poder de la acción estatal en su aspecto relacional, es decir, cómo aumentan o dificultan la formación de capacidades relacionales para entregar infraestructura de metro. El análisis cualitativo de los datos sugiere que el diseño de los arreglos institucionales y sus cambios inciden en la disponibilidad y movilización de actores, recursos, competencias e instrumentos políticos para promover la efectividad y legitimidad de esta política pública.

Palabras-clave: capacidad de políticas públicas, arreglos institucionales, infraestructura urbana 


\section{Introduction}

Urban infrastructure can be understood as the material structure that supports the provision of public services in an urbanized area. Any public service requires some support for its implementation. However, in some cases this material support is the very means by which such public services reach the citizens (IPEA, 2010). This is the case of urban mobility, a public policy that relies heavily on the construction of support infrastructure. Acknowledging this, this paper focuses on infrastructure policies for urban mobility, especially on the subway modal, in order to investigate how its institutional arrangements determine policy capacity building.

Considering the specificities of the infrastructure sector, this paper presents results of empirical research carried out in an effort to explain how elements of the institutional arrangements of urban infrastructure policies (GOMIDE \& PEREIRA, 2018; LOTTA \& FAVARETO, 2016, 2018; LOTTA \& VAZ, 2015; LOUREIRO et al., 2014, 2015) may condition the building of policy capacities (Wu et al., 2015), especially relational capacities (PereIRA, 2014; Gomide \& PiRES, 2014, 2016).

Drawing from the state capacities literature and the available and produced data from Salvador's subway construction, this paper aims to answer the following research question: how did institutional arrangements influence policy capacity building in the construction process of Salvador's subway system?

The main empirical source of the project are documents produced by both institutions involved in the public policy, as well as by organizations related to policy implementation, such as the Institute of Applied Economic Research (IPEA) and control agencies, especially the Audit Courts. These primary data were complemented by the analysis of 15 original in-depth, semi-structured interviews with local actors involved in the implementation of the Salvador subway, from members of the municipal and state bureaucracy to representatives of civil society. This material was used for content analysis, in an effort to identify state capacities, capacity mobilization processes and the relationship between capacities and the different institutional arrangements and their attributes.

This article is structured into four sections, in addition to this introduction. The first section puts forward the theoretical framework used to demonstrate the relations between policy capacities and institutional arrangements. The second section describes 
the empirical case analyzed: the process of construction of the Salvador and Lauro de Freitas subway. The third section analyses the data collected based on the empirical case derived from the categories presented in the theoretical framework. Finally, the fourth section presents the conclusions of this paper and an indication of the potential improvements that can contribute to the studies of policy capacities.

\section{Policy capacities and institutional arrangements}

According to first studies on state capacities, the results of state action may be explained by the presence (or absence) of resources, instruments and structures within public organizations (EvANS et al., 1985). Conceived as organizations that claim control over territories and people, states are actors capable of formulating and implementing their own goals (SKOCPOL, 1985). Therefore, the concept of "state capabilities" was first used by historical new institutionalism as an attempt to explain state autonomy (SKOCPOL, 1985).

Cingolani (2013) divides the literature into two generations of state-based studies: (i) state-building studies and (ii) studies on state agency. The first generation had established a concept of state capacities to explain situations in which states emerge, manage internal and external conflicts, and transform their societies and economies. State building studies may have been originally concerned with understanding the formation of states, that is to say, their construction and differentiation vis-à-vis the society (TILLY, 1975; SKOCPOL, 1979), while the second generation seeks to explain the constraints imposed on and opportunities generated by state action.

This latter generation investigates the capacities that state organizations possess (or not) to effectively achieve given objectives through public policies, such as the provision of goods and services. Therefore, the effectiveness of state agency and the degree of its autonomy to act are directly determined by the ways in which state-society relations are intertwined. In fact, innovative studies have questioned this apparent polarization between State and society and developed the notion of constant interaction and processes of mutual influence (MigDAL, 1988; EvANS, 1995).

Therefore, the study of the state cannot be limited to the analysis of state organizational conflicts and internal dynamics. It should rather be especially focused on its porosity regarding social and economic environments and resource mobilization and 
those instruments that allow these state organizations to process and respond to such stimuli (EvANS, 1995; PEREIRA, 2014).

Therefore, state capacities concern the resources, skills and instruments mobilized within public policies that enable state agency, especially its ability to formulate and implement decisions in collaboration with civil society and stakeholders. The analysis of state agency through the approach of policy capacities contributes to the explanation of policy results, at the same time as it allows for viewing this concept as a dynamic category. In other words, policy capacities do not exist as objects made of matter in the empirical world, as resources and instruments available to state organizations. Differently, policy capacities are built (PAINTER \& PIERRE, 2005; BICHIR, 2015).

The literature draws attention to the roles played by different capacities in different situational contexts (MATUS, 1991; LOUREIRO et al., 2018). In other words, a qualified element as a mobilizer of capacities in a given period and in a given politicalinstitutional context can be considered a hindrance at a later time or in another location. In view of this, the investigation of state capacities must be carried out considering not only the characteristics of the context in which they are inserted, but, above all, the maturity term to which the related public policies are subjected, in order to configure new objectives and obstacles (BICHIR, 2015). Therefore, a steady and constant approach to state capacities capabilities on the same policy has little to contribute to the debate about state agency power. After all, capacities may vary not only between different public organizations (SKOCPOL \& FINEGOLD, 1982) involved in the same policy, but mainly throughout this policy as it is implemented.

According to Loureiro et al. (2018), public policy capacities are related to the exercise of state power, linked to ideological priorities. In this sense, changes in public priorities, thus, in the political project of government (MATUS, 1994) ought often to provoke changes in the institutional arrangement of policies and, consequently, in the conditions for state agency.

It is possible to observe and measure the resources that state organizations employ to increase policy results, in order to indirectly estimate conditions that make state action feasible (Lindvall \& TEORELL, 2016). These conditions may be expressed by the institutional arrangement formed to enable the policy analyzed.

This shift from a State-centered perspective to a State-in-society approach proposes an update to the entire discussion on state capabilities and the autonomy of 
States. The patterns of state performance are also determined by the pressures of social clashes under state leaders, constantly occurring in the multiple social arenas of domination and opposition.

In response to these criticisms of the concept of state capacity, the concept of state capacity was expanded to include elements of political representation, conflict resolution, and administrative porosity. In other words, the concept has been updated to encompass the dimension of state responsiveness to social provocations and its accountability towards civil society, so that public action would also involve the instruments and mechanisms in charge of processing and resolving conflicts arising from the public policy process (GRINDLE, 1996).

Considering that capillarity is required for the success of public action, the state should be in constant exchange and dialogue with external actors to maintain its legitimacy. If this premise is true, then one should not speak of bureaucratic insulation as the sole vector of state autonomy, but rather argue that state capacities are determined by the abilities of bureaucracies to relate with one another and to process conflicts with other organizations, economic agents and social actors.

In other words, the result of public policies is also influenced by the way in which the State articulates the network of actors involved in the implementation (PEREIRA, 2014). This idea illustrates a development of the classic notion of bureaucratic insulation and state autonomy (GEDDES, 1994). Thus, political-relational capacities are a manifestation of the embedded autonomy of the State, considering that state organizations are also determined by the relations maintained by bureaucrats and political leaders and external stakeholders (Evans, 1995; PEREIRA, 2014; GOMIDE \& PIRES, 2014, 2016; LOUREIRO et al., 2014, 2015).

Policy capacity could thereby be the result of a balance between two apparently antagonistic vectors: performance of economic and social intervention and political support. According to this approach, state capacity is directly linked to the insulation by bureaucratic agencies, not of interest groups, but of clientelistic political pressures (personal and partisan) by actors who would try to appropriate the resources of these organizations (GEDDES, 1994).

From this perspective, policy capacity is understood as the bureaucratic development of state agencies (SOUZA, 2017), through the establishment of meritocratic processes and technically-based personnel selection processes as well as the availability 
of funds and materials, towards an insulation and protection of their resources subject to the clientelistic distribution dynamics of state resources, as a strategy to build political support for the government.

Thus, the idea of insulation may be replaced by the concept of embedded autonomy, that is to say, an autonomy before society and the economy (EvANS, 1995). Peter Evans (1995, p. 12) defines embedded autonomy arguing that:

\begin{abstract}
The internal organization of developmental states comes much closer to approximating a Weberian bureaucracy. Highly selective meritocratic recruitment and long-term career rewards create commitment and a sense of corporate coherence. Corporate coherence gives these apparatuses a certain kind of "autonomy." They are not, however, insulated from society as Weber suggested they should be. To the contrary, they are embedded in a concrete set of social ties that binds the state to society and provides institutionalized channels for the continual negotiation and renegotiation of goals and policies. Either side of the combination by itself would not work. A state that was only autonomous would lack both sources of intelligence and the ability to rely on decentralized private implementation. Dense connecting networks without a robust internal structure would leave the state incapable of resolving "collective action" problems, of transcending the individual interests of its private counterparts. Only when embeddedness and autonomy are joined together can a state be called developmental.
\end{abstract}

Therefore, the increase of policy capacities requires the development of state structures, not only to formulate and implement state own goals, but also to establish links with society in order to mobilize stakeholders towards the direction of policy implementation (EvANS, 1995). Nevertheless, it does not mean that bureaucracies should be closed to dialogue with the external environment. In brief, bureaucratic insulation refers to the immunization of the bureaucracies against the political dynamics so that their resources are not used as a currency in the pursuit of support and formation of coalitions (GEDDES, 1994).

In democratic contexts, state capacity should not be conceptualized as a feature of state organizations to become fully independent of the environment and social forces. Instead, state capacities ought to be associated with the idea of embedded autonomy. In other words, the increase of policy capacity is rather conditioned by the existence of state cells with the ability to relate to each other and to stakeholders of that particular public policy area.

Therefore, the state's ability to implement policies relies on an effective bureaucratic machine equipped with sufficient resources to assert its decisions in spite of resistance of the dominant classes, while also allowing exchanges with social and market dynamics (EvANS et al., 1985). 
Yet, bureaucratic insulation explains only a portion of state performance, since state intervention also depends on the way in which State-Society relations take place in the institutional arrangements of public policies (LOTTA \& VAZ, 2015; GOMIDE \& PIRES, 2014, 2016; LOTTA \& FAVARETO, 2016, 2018; LOUREIRO et al., 2014, 2015).

The most contemporary understandings of the concept of state capacity are concerned with understanding the action of States within the scope of public policy performance, seeking to understand the elements that influence coordinated action within the institutional arrangements of the respective policies. According to this notion, the analysis of public organizations' performance can be represented in the idea of capacities for public policies (policy capacity), defended by $\mathrm{Wu}$ et al. (2015). From the understanding of these authors, policy capacity is conceptualized as a set of skills and resources necessary for public organizations to act effectively in the development of public policies. Divided in a tripartite manner, the competencies comprise the skills, which may be (i) analytical, (ii) operational and (iii) political, and resources, which are disposed according to one of following scales: (a) individual, (b) organizational and (c) systemic. Therefore, this conceptual model defines policy capacity as the result of the combination of resources and skills in each of these dimensions (WU et al., 2015).

Therefore, state capacities for public policies can be seen as the mobilization of resources and competences, within the scope of a given policy, on an individual, organizational scale or on the systems in which this policy is inserted (LIMA, 2019).

The literature draws attention to the roles played by different capacities in different situational contexts (MATUS, 1991; LOUREIRO et al., 2018). In other words, a qualified element as a mobilizer of capacities in a given period and in a given politicalinstitutional context can be considered a hindrance at a later time or in another location. In view of this, the investigation of state capacities must be carried out considering not only the characteristics of the context in which they are inserted, but, above all, the maturity term to which the related public policies are subjected, in order to configure new objectives and obstacles (BICHIR, 2015).

Therefore, a steady and constant approach to state capacities on the same policy has little to contribute to the debate about state agency power. After all, capacities may vary not only between different public organizations (SKOCPOL \& FINEGOLD, 1982) involved in the same policy, but mainly throughout this policy as it is implemented. 
According to Loureiro et al. (2018), public policy capacities are related to the exercise of state power, linked to ideological priorities. In this sense, changes in public priorities, thus, in the political project of government (MATUS, 1994) ought often to provoke changes in the institutional arrangement of policies and, consequently, in the conditions for state agency.

The federative approach is an imperative dimension in the analysis of the reality of the Brazilian State after 1988, considering the distribution of institutional competences among the political entities of the federation. Different levels of government have different scopes of action in a given domain, which must be considered when measuring the capacities of each one, considering their participation in the studied policies (GRINDLE, 2007; \& SOIFER, 2012).

In fact, when considering the federative organization of the Brazilian State and the multiplicity of public, private, and civil society organizations that effectively participate in the implementation of public policies, the study of state capacities is not equivalent to the analysis of isolated institutions, but rather their networking with other organizations (PEREIRA, 2014; \& MORTARA, 2017).

Thus, between the organizational scale and the systemic scale, another analytical level should be added: the approach of institutional arrangements (LOTTA \& VAZ, 2015). Institutional arrangements can be defined as the set of rules, mechanisms and processes that define the way in which actors and interests are articulated in the implementation of a specific policy ( GOMIDE \& PIRES, 2014)

In other words, the result of a public policy can also be explained by the institutional arrangement through which the performance of different actors (individuals and organizations) is regulated in the implementation process, in a way that the institutional arrangement of a public policy conditions the definition of policy capacities involved in its production (LOUREIRO et al., 2014; PEREIRA, 2014;GOMIDE \& PIRES, 2014, 2016).

In this sense, the institutional arrangement of a given public policy may condition the process of mobilization of resources, skills and instruments by organizations in charge of the implementation of the policy and can affect availability, that is, access to these elements, or even the activation/mobilization of these attributes. Thus, the potential effectiveness of state action is also conditioned by the way in which a network of 
stakeholders (state and non-state) are articulated towards policy implementation (PEREIRA, 2014).

Gomide and Pires (2014) define institutional arrangements as the specific rules established to define economic, political and social transactions within policy framework to coordinate this network of interests, delimiting who is entitled to participate in a given process, its purpose and objectives, as well as relationships formed between different actors. In other words, the arrangement represents the specific rules of the "policy game", established to coordinate players' actions towards accomplishing policy goals. Therefore, institutional arrangements define who does what on each phase of the policy process.

Previous studies have shown that institutional arrangements for implementing urban mobility infrastructure influence state action and the effectiveness of these policies (PAUlA, 2014; \& PereirA, 2017). In this way, the embedded autonomy can be constructed based on the institutional arrangements of infrastructure policies through which state and non-state actors interact within the implementation process.

As a result, this article attempts to test the way in which policy capacities are defined by institutional arrangement, whether they condition public organizations' agency and, consequently, policy outputs. Relying on previous studies on the public policy regarding the construction of Salvador's subway system (SANTANA, 2017; Olivieri, 2018; LOTTA \& FAVARETTO, 2018; GOMIDE et al., 2018), the goal of the research is to explain how changes in the institutional arrangement of Salvador's subway influenced different processes of policy capacity building to deliver this infrastructure.

In other words, the contextual variations along the Salvador subway project can be understood through the theoretical key of public policy production capacities (PAINTER \& Pierre, 2005; Wu et al., 2015; LindVAll \& Toerell, 2016), from an analysis of the variations of the institutional arrangement that condition the mobilization of stakeholders and resources towards the implementation of the subway infrastructure.

\section{Empirical Case: the construction of Salvador's subway system}

Although the project of building a subway in the city is older (SANTANA, 2017), implementation of Salvador's subway started in 1997, as a result of negotiations between the International Bank for Reconstruction and Development (IBRD) - an institution belonging to the World Bank Group (WB) - and the three levels of Brazilian government (Federal government, State of Bahia and Municipality of Salvador). Although there was 
participation of all federal spheres, it is important to point out that the construction of the infrastructure was first designated by the municipality which, in 1999, created the Transport Company of Salvador (CTS), intended for the building and operating of the new subway system. This project was among the promises of modernization and expansion of the rail network provided for in the Program of Decentralization of the Systems of Urban Railroad Transit of Passengers for the capital of Bahia.

The first contract was signed in 1999 and in the initial schedule the completion of the project would have occurred in 2003. The work schedule was constantly extended over the years without, however, any of the successive municipal governments being able to deliver the subway in operation. In 2013, after negotiations between local, state and federal government, the project was transferred to the State of Bahia, which was able to deliver the first operating subway line the following year. On this occasion, the CTS was transferred to the federal state for administration and has since become the Transport Company of the State of Bahia. Table 1 below shows the chronology of the project from the signing of the first contract until the time the subway started to operate.

Table 1 - Chronology of Salvador's subway construction

\begin{tabular}{|c|c|c|c|c|}
\hline Period & $1997-2005$ & $2005-2007$ & $2007-2012$ & $2012-2014$ \\
\hline $\begin{array}{l}\text { Implementation } \\
\text { responsibility }\end{array}$ & \multicolumn{3}{|c|}{ Municipal government (CTS) } & State of Bahia \\
\hline $\begin{array}{c}\text { Related } \\
\text { National Policy }\end{array}$ & $\begin{array}{c}\text { Decentralization } \\
\text { Program for Urban } \\
\text { Trains }\end{array}$ & $\begin{array}{c}\text { Federal } \\
\text { resources } \\
\text { replace foreign } \\
\text { capital (IBRD) }\end{array}$ & $\begin{array}{l}\text { Growth } \\
\text { Acceleration } \\
\text { Program } \\
\text { (PAC) }\end{array}$ & $\begin{array}{c}\text { Growth } \\
\text { Acceleration } \\
\text { Program } 2 \\
\text { (PAC 2 - } \\
\text { Urban } \\
\text { Mobility) }\end{array}$ \\
\hline Coordination & $\begin{array}{c}\text { International Bank } \\
\text { for Reconstruction } \\
\text { and Development } \\
\text { (IBRD) }\end{array}$ & \multicolumn{2}{|c|}{ Federal Government } & State of Bahia \\
\hline $\begin{array}{l}\text { Contractual } \\
\text { Bonds }\end{array}$ & $\begin{array}{c}\text { IBRD Loan } \\
\text { Agreement } \\
\text { Contract SA-01- } \\
\text { Build the } \\
\text { infrastructure } \\
\text { Contract SA-12- } \\
\text { Operation, } \\
\text { Maintenance, Trains, } \\
\text { Telecommunications, } \\
\text { Signaling system }\end{array}$ & $\begin{array}{l}\text { First Agreement } \\
\text { between } \\
\text { Federal } \\
\text { government and } \\
\text { Municipal } \\
\text { agreement - } \\
\text { Funding } \\
\text { Transference to } \\
\text { Line } 01\end{array}$ & $\begin{array}{c}\text { Second } \\
\text { Agreement - } \\
\text { Federal } \\
\text { government - } \\
\text { Funding } \\
\text { Transference } \\
\text { to Line } 01\end{array}$ & $\begin{array}{c}\text { Agreement } \\
\text { between State } \\
\text { of Bahia and } \\
\text { Municipal } \\
\text { government - } \\
\text { Transfer of the } \\
\text { subway project } \\
\text { Agreement } \\
\text { between } \\
\text { Federal } \\
\text { government } \\
\text { and State of } \\
\text { Bahia - } \\
\text { Federal } \\
\text { funding }\end{array}$ \\
\hline
\end{tabular}

Source: Compiled by authors. 
The process of implementation of the subway infrastructure was chosen as a case study not only because of results of previous research, but also because of the particularities of this case. Although studies on this topic often focus on successful cases, investigations into state capacities may rely on cases sometimes classified as unsuccessful state action (SCKOPOL, 1985).

Previous research has indicated that this policy faced several difficulties throughout its execution, which led to discontinuities, delays and inertia in the infrastructure construction (LOTTA \& FAVARETTO, 2016; OLIVIERI, 2016; SANTANA, 2017; GoMIDE et al., 2018). Furthermore, prior studies have pointed out that the failure attributed to the Salvador subway case could be related to issues of lack of policy capacities (OLIVIERI, 2016; SANTANA, 2017; GOMIDE et al., 2018).

In addition, the process of implementation of the Salvador and Lauro de Freitas Subway System has undergone constant changes, including shifts in the roles of the actors involved, inclusion of different policy instruments, adoption of different contract modalities, and modification of the government project (MATUS, 1991; LOUREIRO et al., 2018) which could clarify the link between policy capacities (WU et al., 2015) and institutional arrangements.

Over the years of its implementation, the institutional arrangement of this subway system has undergone different modifications that seem to be related to the different patterns of state action in the different stages analyzed. In this way, the case of the Salvador subway presents a variation of institutional scenarios that could be useful to elucidate the role played by institutional arrangements, so as to investigate how changes in the different arrangement configurations conditioned the mobilization of policy capacities to construct urban infrastructure (LIMA, 2019). In other words, this is a case in which we can see how variations in the institutional arrangement are related to policy.

This evidence allows us to consider this case as a useful laboratory for investigating conditions that enable the state action of urban mobility infrastructure implementation, qualifying it as an object of study likely to raise theoretical contributions to the debate about the building process of policy capacities from institutional arrangements of public policies. 


\section{Research methods}

The main empirical source of the project are documents produced by both the institutions involved in the public policy, as well as by organizations related to policy implementation, such as IPEA and control agencies, especially the Audit Courts. These primary data were complemented by the analysis of 15 original in-depth, semi-structured interviews with local actors involved in the implementation of the Salvador subway, from members of the municipal and state bureaucracy to representatives of civil society. This material was used for content analysis, in an effort to identify state capacities, capacity mobilization processes and the relationship between capacities and the different institutional arrangements and their attributes.

Considering this research is based on a single case study, the data was collected from empirical research previously carried out on the same policy (SANTANA, 2017), derived from documents stored by public institutions, as well as reports of interviews with actors who had direct or indirect participation in the policy process. A compilation of these sources was gathered and the data processed using qualitative methods in order to highlight the way in which elements of the institutional arrangement may influence the formation of relational capacities in each of the phases of the policy process.

The analytical framework (presented in the model further below) shows relationships between (i) types of relational capacities verified in the construction of Salvador's subway (first column), (ii) empirical elements of the institutional arrangement which influence the formation of these relational capacities (second column) and (iii) the variations and changes faced by the institutional arrangements along the three phases in which the policy process was divided (third, fourth and fifth column).

The relational dimension of the institutional arrangement provides the state organization certain elements that in turn can increase or reduce the conditions that enhance agency for the implementation of the policy. The goal is to evidence transformations of the relational dimension of the institutional arrangement of Salvador's subway system and how modifications of such arrangement influenced the building of relational conditions.

The relational dimension of the institutional arrangement is analyzed as a conditioning factor for the construction of (i) capacities aimed at internal coordination of state actors - of the executive power and of the same federative level - directly responsible 
for policy production (ENAP, 2018), as well as for the activation of (ii) political capacities aimed at mobilizing non-state and state actors not included in that first group, involving them in political processes, in order to foster legitimacy and reduce vetoes (LOUREIRO $e t$ al., 2014; PEREIRA, 2014; Wu et al., 2015; GOMIDE \& PiRES, 2016; MORTARA, 2017; ABERS, 2018).

Considering previous investigations regarding policy capacities and institutional arrangements (WU et al. 2015; GOMIDE \& PIRES, 2014, 2016; ENAP, 2018; FIANI, 2013), we propose the analytical model exhibited below:

Table 2 - Analytical framework model of relational capacities

\begin{tabular}{|c|c|c|c|c|}
\hline $\begin{array}{l}\text { POLICY } \\
\text { CAPACITY }\end{array}$ & $\begin{array}{l}\text { EMPIRICAL ELEMENT FROM } \\
\text { THE INSTITUTIONAL } \\
\text { ARRANGEMENT }\end{array}$ & $\begin{array}{l}\text { PHASE } 1 \\
(1997-2005)\end{array}$ & $\begin{array}{l}\text { PHASE } 2 \\
(2005-2011)\end{array}$ & $\begin{array}{l}\text { PHASE } 3 \\
(2011-2014)\end{array}$ \\
\hline \multirow{2}{*}{$\begin{array}{l}\text { Internal } \\
\text { Coordination }\end{array}$} & Centrality in the public agenda & & & \\
\hline & Coordination structure & & & \\
\hline \multirow{5}{*}{$\begin{array}{l}\text { Political } \\
\text { Capacities }\end{array}$} & Federative relations & & & \\
\hline & Relations with control agencies & & & \\
\hline & $\begin{array}{l}\text { Relations with economic } \\
\text { stakeholders }\end{array}$ & & & \\
\hline & Relations with civil society & & & \\
\hline & $\begin{array}{l}\text { Relations with international } \\
\text { organizations }\end{array}$ & & & \\
\hline
\end{tabular}

Source: Adapted by authors from Lima (2019, p. 81).

\section{Findings}

\subsection{Internal coordination capacities}

In advance, it should be clarified that internal coordination should not be understood here as an administrative coordination, which as such would be contemplated in the technical-managerial capacities, but rather as institutional coordination of actors of the bureaucracies involved in the Salvador subway project.

The Salvador subway was conceived as a public policy based on the campaign promises of Mayor Antonio Imbassahy, whose election for the 1997-2000 term in the city 
gave materiality to the idea (SANTANA, 2017). The first two years of this mandate were the scene of negotiations between the three federative spheres as well as with IBRD, while the last two years were marked by the definition of the project's design and the bidding for the two main contracts. In the first four years, it can be inferred that the subway project was central to the agenda of local governments, both state and municipal, and the federal government.

It is not incidental that the project was coordinated by a body created specifically for central government projects, linked directly to the mayor's office: The Municipal Secretary for Investment Promotion and Strategic Projects (SEMPI). Until 2000, SEMPI served as an instrument for coordinating project activities and maintaining policy with a central focus on the government agenda.

In the second period of phase I (2001-2004), there is still continuity of government in relation to the project. However, SEMPI is extinguished, so that the CTS passes to the Municipal Secretariat of Urban Transportation (SMTU), along with the subway project. In this context, the former Secretary of SEMPI and also CEO of CTS becomes the municipal secretary of urban transport.

Despite maintenance of the project amidst these variations, the analysis of some interviews allows us to infer that the relevance of the subway project diminished in the municipal government agenda, a phenomenon also verified in other studies on capacities (LOUREIRO et al., 2018). In other words, there is a continuity of both the government and the leaders involved, yet the project loses some prominence in the list of public policy priorities. Regarding the state and federal governments, there is not enough data to draw conclusions and make relationships between these variables.

In contrast, the position that the Salvador subway project occupies in government agendas is completely changed with the advent of phase 2 . It is worth noting that the event that marks the transition to phase 2 - the transfer of urban trains to the government - seems to have been one of the main causes for the reconfiguration of government priorities.

At first, from a federal government perspective, building a subway system has never been on the national agenda, but rather was a political bargain negotiated between local governments so that the federal government could implement its own interests under the Urban Train Decentralization Program (PDTU): the transfer to local power of the Salvador urban train system, hitherto operated and managed by CBTU. 
From another point of view, the Salvador subway has lost centrality in the municipal government agenda for a number of reasons. Firstly, because there was a change of government in 2005, with the election of candidate João Henrique as mayor of Salvador. Secondly, because the municipality was overwhelmed by the administration and operation of suburban trains which, according to interviews, may have drained the subway project's financial, human and technical resources, as both suburban and suburban train systems were under the responsibility of CTS. The analysis of documentary data and interviews leads to the conclusion that the subway, as a public policy, would have significantly lost its prominent place in the municipal government agenda.

Nor does it appear that instruments to coordinate project activities had been mobilized at this time, as the data do not indicate any support from the institutional arrangement to CTS for project implementation. In fact, the scarcity of information about the local arrangement at this stage seems to suggest the absence of a larger CTS support network, which seems to point to the hypothesis that during this period the municipal company was on its own in the challenges of managing local contracts and federal agreements.

On the other hand, it could be suggested that the Salvador subway was more relevant in the federal government's perspective, from its inclusion in the Growth Acceleration Program (PAC) project portfolio. Despite such visibility, the project also drew the attention of control agencies, which led to criticism and irregularities pointed out in the project hiring.

In phase 3 of the project, in turn, the arrangement has changed too much with respect to this variable. First, because of the transfer, the project is not only off center, but completely out of the municipal government's agenda, which now assumes the role of obstacle, at times hindering the progress of the project. Secondly, on the verge of the project being handed over to the state, the Salvador subway had its public image and credibility completely annihilated, such that the state would absorb not only a source of national shame to the local population, but also a major challenge for the state public policy. As is clear from the interviews, the risk taken by the state was too high. If it were to fail, the negative image of the project would damage the reputation of the state government, but if the state of Bahia were successful in delivering the subway, it would gain a great reputation for success. 
In phase 3 of the project, either due to the imminence of the FIFA World Cup, or for other reasons, the Salvador subway project emerged strongly on the federal government's agenda, which facilitated its inclusion in PAC II. This resumption as a federal government priority was an essential element for the availability of financial resources and support for the state government on other project fronts, such as the change in federal Public-Private Partnership (PPP) legislation.

In phase 3, the PPP contract itself can be understood as an instrument of project coordination, mainly because it contains in itself all the works and services for the completion of the implementation of Line 1, construction of Line 2 and operation of the subway system project. Being only a single contract, the PPP enabled greater coordination of activities by the State of Bahia, since the management and supervision lay only with the concessionaire, who was responsible for contracting works and services necessary for the implementation of infrastructure.

In addition, the institutional arrangement in phase $3 \mathrm{had}$ an important instrument of coordination, starting from the creation of a working group in the State of Bahia, composed of representatives of the main state organizations to conduct the formulation and execution activities of the subway system project. According to the analysis of the interviews, this working group comprised representatives of CTB, SEDUR-BA, SEFAZBA, PGE-BA, Casa Civil-BA and external consultants hired to provide technical support to the work.

Finally, from the data analyzed in this research, it is worth pointing out the notable lack of presence, in all three phases, of certain categories of bureaucracies: (i) organizations for the preservation of cultural heritage, (ii) bodies responsible for environmental licensing and (iii) regulatory bodies of public passenger transport. These actors appear very marginally from interview reports and documentary records.

The lack of visibility of these bodies can be interpreted as indicative of their low involvement in the institutional arrangement of Salvador's subway implementation. A possible explanation for this hypothesis is linked to the very characteristics of the subway engineering project, whose great part of the route runs through the central highways of the city, except for two stations which are underground and situated in historic areas of the city center. In other words, the urban spaces in which the subway's physical infrastructure was designed involved few areas with environmental and cultural heritage elements, which could explain the absence of mention of these organizations in the data 
collected in this research. This hypothesis corresponds with the conclusions of previous studies, which already pointed out that the delays in the Salvador subway works were not caused by environmental licensing issues (PEGO et al., 2018).

In fact, heritage bodies were mentioned superficially in one interview, specifically regarding the underground works of the two stations that occurred in phase 1, but still, nothing very significant for the objectives pursued by this research. In this sense, differently from what is often pointed out by infrastructure policy studies, the data analyzed in this case did not point to relations with bureaucracies for the preservation of cultural heritage and the environment as significant conditions of internal coordination capacities.

On the other hand, the evidence that public transport regulators would not have actively participated in politics seems to point to an incompleteness of the institutional arrangement in involving these bureaucracies. One of the reports expressly points out that AGERBA, the body responsible for regulation of the metropolitan bus lines, was belatedly involved in the institutional arrangement of the subway system when conflicts between the state of Bahia, the city of Salvador and municipal bus concessionaires were already fierce. According to this report, AGERBA would not have been included in the discussions until the modal and tariff integration with tire transport threatened the food and operational viability of the subway project, at which time the agency would have been involved to promote readjustments in the lines of metropolitan buses.

Finally, none of the information collected made any mention of the participation of bodies of the municipality of Salvador responsible for regulating urban mobility.

Table 3 - Internal coordination capacities

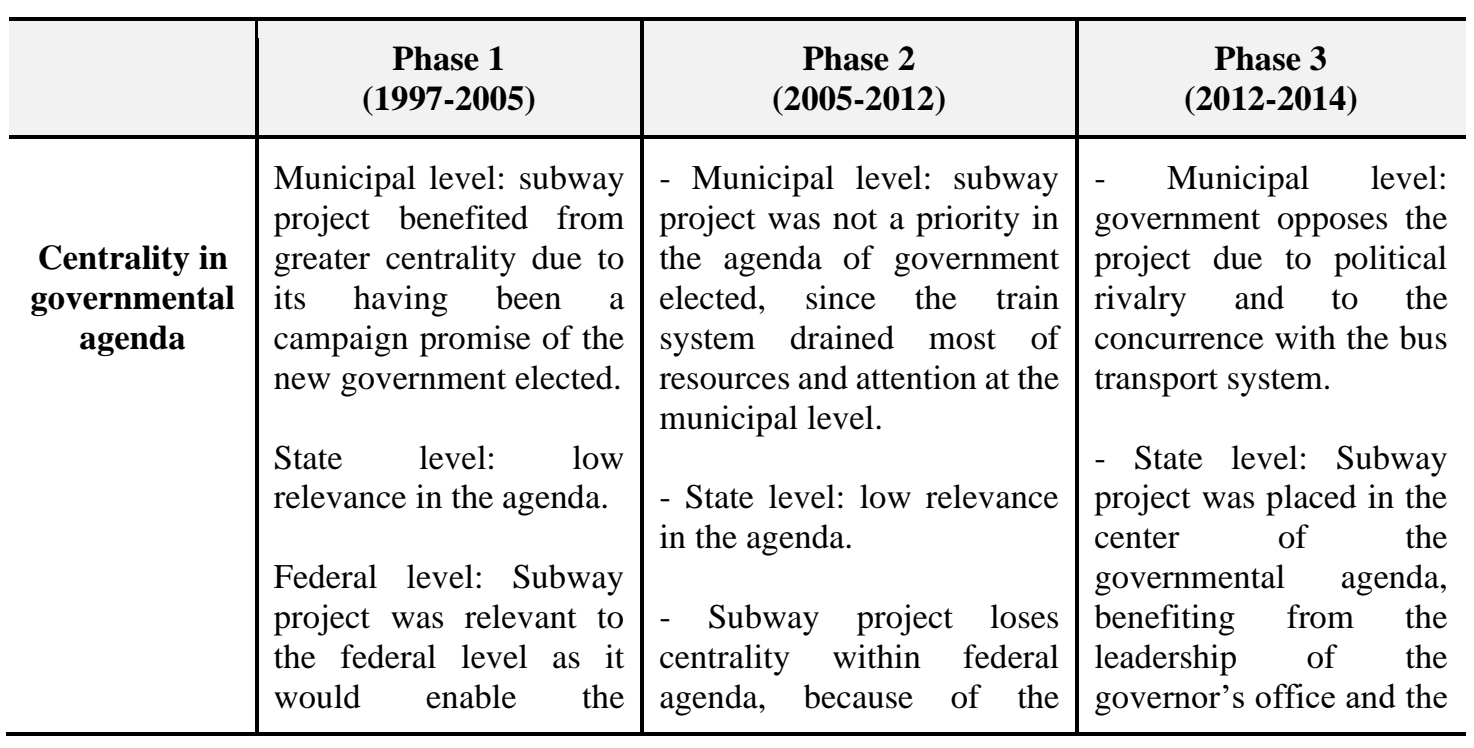




\begin{tabular}{|c|c|c|c|}
\hline & $\begin{array}{c}\text { Phase 1 } \\
(1997-2005)\end{array}$ & $\begin{array}{c}\text { Phase } 2 \\
(2005-2012)\end{array}$ & $\begin{array}{c}\text { Phase } 3 \\
(2012-2014)\end{array}$ \\
\hline & $\begin{array}{l}\text { transference of the train } \\
\text { system administration to } \\
\text { the local level. }\end{array}$ & $\begin{array}{l}\text { complete transference of the } \\
\text { train system to municipal } \\
\text { level. }\end{array}$ & $\begin{array}{l}\text { Office of the Chief of } \\
\text { Staff at the state level. } \\
\text { - Federal level: the } \\
\text { project benefited from } \\
\text { greater centrality, due to } \\
\text { the imminence of } \\
\text { international sports } \\
\text { events to take place in } \\
\text { Brazil and political } \\
\text { alignment with state } \\
\text { government. }\end{array}$ \\
\hline Outputs & $\begin{array}{l}\text { Municipal and federal } \\
\text { organizations were } \\
\text { highly engaged in the } \\
\text { project. }\end{array}$ & $\begin{array}{l}\text { Municipal and federal } \\
\text { organizations showed low } \\
\text { engagement in the project. }\end{array}$ & $\begin{array}{l}\text { State and federal } \\
\text { organizations highly } \\
\text { engaged in the project. } \\
\text { Municipal organizations } \\
\text { opposed to the project. }\end{array}$ \\
\hline $\begin{array}{c}\text { Coordination } \\
\text { Structure }\end{array}$ & $\begin{array}{l}\text { - 1997/2001: } \begin{array}{r}\text { SEMPI } \\
\text { placed } \\
\text { leadership, } \\
\text { closely to the mayor's } \\
\text { office. }\end{array} \\
\text { - 2001/2004: SEMPI's } \\
\text { extinction. Subway } \\
\text { project is transferred to a } \\
\text { sectoral body placed in a } \\
\text { lower hierarchical level. }\end{array}$ & $\begin{array}{l}\text { - There is no evidence of a } \\
\text { sophisticated structure for } \\
\text { coordination. }\end{array}$ & $\begin{array}{l}\text { - A Working Group } \\
\text { structure is created at } \\
\text { state level with the } \\
\text { participation } \\
\text { organizations involved in } \\
\text { the project. } \\
\text { - The PPP contractual } \\
\text { structure is created. } \\
\text { - A metropolitan } \\
\text { agreement is signed } \\
\text { between State of Bahia } \\
\text { and both municipal levels } \\
\text { involved. }\end{array}$ \\
\hline Outputs & $\begin{array}{l}\text { The existence of a } \\
\text { structure directly linked } \\
\text { to the mayor's office } \\
\text { enabled a better } \\
\text { coordination of the } \\
\text { public organizations } \\
\text { involved in the project. }\end{array}$ & $\begin{array}{l}\text { Municipal level faced } \\
\text { difficulties in coordinating } \\
\text { multiple actors involved in } \\
\text { the project. }\end{array}$ & $\begin{array}{l}\text { The working group } \\
\text { enabled the exchange of } \\
\text { information between } \\
\text { state organizations. } \\
\text { The P3 contract defines } \\
\text { responsibilities of State } \\
\text { of Bahia and private } \\
\text { partner. } \\
\text { The metropolitan } \\
\text { arrangement made it } \\
\text { possible to integrate the } \\
\text { subway with the bus } \\
\text { systems (municipal). }\end{array}$ \\
\hline
\end{tabular}

Source: Compiled by authors.

In phase 1 , there seems to have been greater centrality due to campaign promises from the municipal government, which was lost during phase 2 , both at the local level and at the federal level. The project was central to the federal government's 
agenda during phase 1 , which was not the case during phase 2 , since the transfer of administration of suburban trains to the municipal level was carried out. In contrast, during phase 3 the project had great relevance to the agenda of the state government and also to the federal government due to, especially but not only, the imminence of international sport events which would be hosted by Brazil in the following years.

\subsection{Political capacities}

The political capacities built by the Salvador subway implementation arrangements were conditioned on five relational elements, observable in the empirical case: (i) federative relations, (ii) relations with control agencies, (iii) relations with economic stakeholders, (iv) relations with civil society and (v) relations with international organizations.

The specific selection of these relations does not imply that they would have been the only actors involved in the Salvador subway implementation processes ${ }^{1}$. Many others have participated, directly or indirectly, in this policy, however, the data gathered point to the significant influence between capacity building and the relationships dealt with below.

\subsubsection{Federative relations}

Federative relations were a relevant variable in all three phases of the project to build capacity for the implementation of subway infrastructure. This is also one of the variables that points to one of the largest variations over time, indicating fluctuations in capacity levels in each period.

To preface, the inception of the subway project as a public policy is due to the formation of an initial federative arrangement, that is, to a pact between the Federal government, the State of Bahia and the Municipality of Salvador to build a subway system in the Bahian capital. In this first phase, synergies were established especially between

\footnotetext{
${ }^{1}$ This list does not include, for example, actors that are recognized as relevant to the production of public policies, such as those from the legislative and judiciary spheres. The data analysis showed little relevance in the participation of these last categories in what concerns, specifically, the processes of construction of conditions for the state action of implementing subway infrastructure in Salvador.
} 
the municipal and federal governments to support and exchange technical expertise from CBTU to CTS, in the co-management model developed for the project.

In addition, federative relations were an instrumental requirement for building financial capacities, since the involvement of state and especially federal governments provided voluntary transfers of resources so that the municipality could contract the works and services to implement the subway. It is no wonder that thanks to the political articulation with the federal government, the loan with IBRD became viable, based on the provision of guarantees and debt contraction by the federal government.

However, while on the one hand the synergies between Salvador and the federal government were crucial for project financing, they were also responsible for including the Federal Audit Court ("TCU", Portuguese acronym) in the subway implementation arrangement, since the control body is competent to oversee the use of resources. The federal TCU's performance during the first and second phases of the project repeatedly caused delays and inertia in the project's progress due to irregularities. Without going into the merits of the TCU's notes and analyses, it can be stated that federal relations aimed at raising financial resources, although they boosted the building of financial capacities, also created indirect obstacles to state action, since the repeated interventions of that body reduced project continuity.

On the other hand, during phase 2 , federative relations were marked by the assumption by the federal government of the portion of financing previously borne by IBRD. In spite of this intensification of federal resources, relations between the federal government and Salvador changed in such a way that the construction of other types of capacities - for example, techniques - had been compromised, since the co-management model was replaced by a supervisory model. This phase was also marked by distance from the project by CBTU.

According to analysis of the interviews, it can be inferred that the political capacities built in terms of federative relations were lower in phase 2, considering the low engagement of federal and state levels during this period. Regarding the relations between the municipality and the state of Bahia, the lack of political articulation between both entities generated deficiencies in the internal coordination of the project, such as the acquisition of trains for the subway system, at the expense of the state, before the completion of infrastructure works, at the expense of CTS. Regarding the relationship between the municipality and the federal government, although the project was included 
in two policies for receiving federal transfers, the disruption of the co-management model - established in phase 1 - left the CTS helpless and without technical support for the project's construction management. Moreover, there was no building of political capacities towards dialogue with the TCU, as already shown.

In other respects of the third phase, federative relations were one of the main variables that enabled the construction of capacities by the State of Bahia to complete the implementation of the subway infrastructure in a timely manner. First, the articulation between the state of Bahia and the municipalities of Salvador and Lauro de Freitas propelled a federative architecture capable of elevating the subway system to metropolitan proportions. In other words, federative relations were a very important variable for the design of a new arrangement, marked by the introduction of two new instruments (federative agreement and program agreement), which was an indispensable condition for the coordination of actions and interests towards the implementation and operation of a subway system that forms the structure of a metropolitan mobility system. From the point of view of relations with the federal government, these also boosted the mobilization of capacities by the State of Bahia to implement subway infrastructure. Beforehand, the context was of imminent FIFA World Cup games that would be held in some Brazilian capitals, including Salvador, which was why the federal government had a strong interest in Line 1 of the subway system. At this point, the subway's operations had commenced.

In this way, the articulation for the amendment of the federal PPP law, in order to create a new contractual financial device, was responsible for enabling a less costly and faster execution of the project for the government, since it allowed, from a financial and economic point of view, a greater balance between expenses and revenues throughout the implementation phase. In addition, the political articulations with the federal government provided the availability of financial resources, such as remaining PAC onlending, as well as new PAC 2 onleading and BNDES financing.

The analysis of interviews suggests that the unsolicited proposals procedure (PMI) and the PPP enabled a coordination of actors and interests in the form of market mechanisms. Further, the federative agreements established between the State of Bahia and municipal governments (Salvador and Lauro de Freitas) resemble coordination mechanisms in the form of a network (LOTTA \& FAVARETO, 2018). These federative agreements were crucial for inserting the subway according to an integrated rationale of 
metropolitan transport, guaranteeing cooperation of the municipalities with the urban planning issues, besides guaranteeing the non-competition with other models and, consequently, the passenger demand necessary for the self-sufficiency of the Metro Transportation System.

Table 4 - Political capacities to federative relations

\begin{tabular}{|c|c|c|c|}
\hline & $\begin{array}{c}\text { Phase 1 } \\
(1997-2005)\end{array}$ & $\begin{array}{c}\text { Phase } 2 \\
(2005-2012)\end{array}$ & $\begin{array}{c}\text { Phase } 3 \\
(2012-2014)\end{array}$ \\
\hline $\begin{array}{c}\text { Federative } \\
\text { relations }\end{array}$ & $\begin{array}{l}\text { - Federal and state } \\
\text { engagement in } \\
\text { management of the } \\
\text { project and funding. } \\
\text { - Shared management } \\
\text { model structured to } \\
\text { involve the three } \\
\text { federative levels. }\end{array}$ & $\begin{array}{l}\text { - The old train system } \\
\text { administration is transferred } \\
\text { to municipal government. } \\
\text { - Federal government step out } \\
\text { of managerial role for tasks. } \\
\text { - Federal funding rises } \\
\text { - State of Bahia in charge of } \\
\text { purchasing the subway trains. }\end{array}$ & $\begin{array}{l}\text { - Political alignment } \\
\text { between federal and state } \\
\text { governments. } \\
\text { - Metropolitan agreements } \\
\text { between state and both } \\
\text { municipal governments. }\end{array}$ \\
\hline Outputs & $\begin{array}{l}\text { CBTU's engagement } \\
\text { enables capacities to } \\
\text { construction } \\
\text { management. }\end{array}$ & $\begin{array}{l}\text { Lower federal prominence in } \\
\text { managerial tasks contribute } \\
\text { to municipal failure in } \\
\text { executing the project. }\end{array}$ & $\begin{array}{l}\text { Relations between State } \\
\text { and federal government } \\
\text { enable changes in the } \\
\text { national legislation. } \\
\text { Relations between State } \\
\text { of Bahia and municipals } \\
\text { governments enable } \\
\text { integration of the subway } \\
\text { with local bus systems. }\end{array}$ \\
\hline
\end{tabular}

Source: Compiled by authors.

\subsubsection{Relations with control agencies}

One of the most significant variables to explain the mobilization of political capacities in the case of the implementation of the Salvador subway was certainly the relations with control agencies of the public administration.

Initially, since 2001, the subway project had been audited exclusively by the TCU, which repeatedly pointed out irregularities in the two main works and services contracts for the implementation of Line 1. The main difficulties encountered in relations with the TCU referred to CTS's use of IBRD rules for contracting at this stage. By the end of this phase, in addition to these issues, the TCU audits were already beginning to point out suspicions of overpricing in the values of these contracts. In this first stage, relations with the TCU were not driving the project implementation but were equally not impeding its continuation. 
In contrast, in phase 2, the lack of information presented and compliance with the TCU determinations led to multiple delays to executive the work by order of the external controller, reaching its peak with the determination of retention of resources in the payment of the two main contracts of the project.

In addition, the second phase of the subway implementation was marked by interaction with other control bodies, which until then had little notable presence in the execution of the project, according to the analysis of interviews and documentary sources. These include CGU, TCM-BA, MPE-BA and MPF. Those that appear most in the data analysis are the TCU, which is in charge of ascertaining evidence of irregularities in bidding and contracts, the CGU, which is interested in controlling internal processes, and TCM-BA, which is responsible for auditing and judging internal accounts of the CTS.

Relations with TCM-BA were not impeding capacity mobilization but were significant in drawing attention to the financial difficulties that CTS faced in concomitantly driving the operation of suburban trains and the implementation of the new subway system.

Likewise, in phase 3 of the project, changes were found in relations with the control bodies. First, the data analysis points out that, unlike what had been carried out so far, in this third phase, the control bodies were included in the institutional arrangement since the reformulation stage of the project. The inclusion of these bodies from the beginning of the public call or expression of interest process (PMI, Portuguese acronym), culminating in the presentation of the final project modeling, i.e. technical contours of the new contract and bidding, were crucial strategies for building the project's political capacities. In other words, the participation of the control bodies in the policy reformulation process was an element of veto prevention throughout the project implementation stage. Furthermore, it should be noted that the inclusion and mobilization of the MPE-BA in the arrangement of this third stage made it possible to build political capacities to enforce the program agreement, in particular the rules established for the modal and tariff integration of the subway system with bus lines, which were crucial for the implementation of metropolitan management of people mobility.

Analysis of the data seems to support Olivieri's (2016) conclusion that there would have been no overlap of local (TCM-BA) and federal (TCU) external controls on the Salvador subway project. While this statement is true, it is also true that the Salvador subway project has been the target of a plurality of external and internal controls that to 
some extent reduce or affect the continuity of project execution. This conclusion is most applicable to the second phase of the project but is also valid for the remaining steps.

Table 5 - Political capacities to control agencies

\begin{tabular}{|c|c|c|c|}
\hline & $\begin{array}{c}\text { Phase 1 } \\
(1997-2005)\end{array}$ & $\begin{array}{c}\text { Phase } 2 \\
(2005-2012)\end{array}$ & $\begin{array}{c}\text { Phase } 3 \\
(2012-2014)\end{array}$ \\
\hline $\begin{array}{l}\text { Relations } \\
\text { with control } \\
\text { agencies }\end{array}$ & $\begin{array}{l}\text { - First biddings } \\
\text { and contracts are } \\
\text { audited by Federal } \\
\text { Audit } \\
\text { (TCU) }\end{array}$ & $\begin{array}{l}\text { - The state-owned enterprise } \\
\text { in charge of the project (CTS) } \\
\text { is audited by the Municipal } \\
\text { Audit Court (TCM-BA) } \\
\text { - Municipal government fails } \\
\text { to respond to the Federal } \\
\text { Audit Court (TCU) and other } \\
\text { federal control agencies, such } \\
\text { as the Federal Prosecutor's } \\
\text { Office (MPF) and Federal } \\
\text { Comptroller General (CGU). }\end{array}$ & $\begin{array}{l}\text { - Control agencies (MPE-BA, } \\
\text { TCE-BA) are engaged in the } \\
\text { reformulation and execution of } \\
\text { the project. }\end{array}$ \\
\hline Outputs & $\begin{array}{l}\text { Signs of } \\
\text { irregularities in } \\
\text { the contracts } \\
\text { reduce the } \\
\text { reputation of the } \\
\text { project before } \\
\text { public opinion. }\end{array}$ & $\begin{array}{l}\text { In 2009, the works and } \\
\text { federal funding are } \\
\text { suspended by a decision of } \\
\text { Federal Audit Court (TCU). } \\
\text { CTS is considered } \\
\text { underfunded by operational } \\
\text { audits. }\end{array}$ & $\begin{array}{l}\text { The engagement of control } \\
\text { agencies in the reformulation } \\
\text { process prevented later vetoes } \\
\text { in the execution of the project. } \\
\text { Particularly, the engagement of } \\
\text { the Public Prosecutor's Office } \\
\text { played a role as enforcement to } \\
\text { the metropolitan agreement } \\
\text { signed between state and } \\
\text { municipal governments. }\end{array}$ \\
\hline
\end{tabular}

Source: Compiled by authors.

\subsubsection{Relations with economic stakeholders}

Among the elements of the institutional arrangement that made up the implementation of the Salvador subway, relations with economic agents played a significant role in the process of building political capacities. From phase 1 to phase 3, it is worth mentioning the constant performance of an economic actor whose own interests would be affected by the implementation of the Salvador subway: the bus companies in the capital of Bahia, represented by SETPS. 
According to the analysis of several interviews, in all three stages, SETPS was an actor of political resistance to the implementation of the Salvador subway project. In phase 3, it is worth highlighting that the federal government sponsored the Bus Rapid Transit (BRT) project as an alternative to Line 2 of the subway system. However, based on unsolicited proposals procedure (PMI, Portuguese acronym) studies, the State of Bahia opted to proceed with the project to complete Line 1 and expand to a second line that would connect the first with the municipality of Lauro de Freitas.

With regard to phase 1, control agencies - especially the Federal Public Prosecutor's Office - pointed to the existence of evidence of cartel formation among the companies participating in the first stage, especially the contract for the execution of the subway works.

In phase 3, the use of new instruments for mobilizing private actors, such as the PMI and the PPP contractual arrangement, was highlighted. Firstly, the PMI opened up the participation of economic agents in the process of developing a solution for the Salvador subway and metropolitan urban mobility. Also, it is worth mentioning that SETPS actively participated in the unsolicited proposals procedures (PMI), having presented a project of mass transit on tires (BRT) as a mobility solution.

Moreover, the use of the PPP instrument allowed the mobilization of other economic agents in the bidding stage of the subway system. Once the contract was signed, the PPP arrangement, especially the remuneration architecture of the private partner, allowed the contractor's actions and interests to be directed to the swift completion of the works and the commencement of passenger transport operations.

Finally, it should be noted that in all three phases the institutional arrangement lacked the means to involve an important category of actors for the construction of the subway: public service companies with physical infrastructure in the urban space. In this case, the most obvious examples are: (i) EMBASA, the company responsible for drinking water supply and sewage services, COELBA, the concessionaire of electricity services, (iii) BAHIAGÁS, the company responsible for distribution of natural gas, and (iv) the various telecommunications service providers.

Each of these services is provided to the population through an infrastructure network - underground or visible in urban space - that affects and is affected by constructional interventions, such as works to build a subway system. It is almost 
inevitable that undertakings of this nature and size will require relocation of these installed urban networks, so that the involvement of those actors would have been convenient from the planning stage to mitigate future interference in the works.

However, data analysis suggests that this category was not sufficiently involved in the institutional arrangement in any of the three phases. The invisibility of these actors in the documentary records indicates that their participation was not significant. The content of their mention in certain interviews corroborates the hypothesis that these economic agents were only reactively and temporarily involved in the arrangements, that is, whenever the subway works happened upon points of dialogue with these service networks. The lack of relational significance with this category of actor seems to express evidence of territorial blindness (LOTTA \& FAVARETTO, 2016) in the institutional arrangement of the Salvador subway.

Table 6 - Political capacities to relations with economic stakeholders

\begin{tabular}{|c|c|c|c|}
\hline & $\begin{array}{c}\text { Phase 1 } \\
(1997-2005)\end{array}$ & $\begin{array}{c}\text { Phase } 2 \\
(2005-2012)\end{array}$ & $\begin{array}{c}\text { Phase } 3 \\
(2012-2014)\end{array}$ \\
\hline $\begin{array}{l}\text { Relations } \\
\text { with } \\
\text { economic } \\
\text { stakeholders }\end{array}$ & $\begin{array}{l}\text { - Investigations (MPF) have } \\
\text { later shown evidence of cartel } \\
\text { formation among the } \\
\text { companies participating in } \\
\text { the bidding of the public } \\
\text { procurements. This fact } \\
\text { highlights a lack of public } \\
\text { transparency and compliance } \\
\text { mechanisms within the } \\
\text { institutional arrangement. }\end{array}$ & $\begin{array}{l}\text { - Subway project faces } \\
\text { strong opposition from } \\
\text { the bus line companies. }\end{array}$ & $\begin{array}{l}\text {-The unsolicited } \\
\text { proposals procedure } \\
\text { (PMI) } \\
\text {-Agreements are signed } \\
\text { between State and both } \\
\text { municipal governments } \\
\text { in order to turn the } \\
\text { subway a metropolitan } \\
\text { project. }\end{array}$ \\
\hline Outputs & $\begin{array}{l}\text { The public procurements are } \\
\text { overpriced, demanding more } \\
\text { budgetary resources. }\end{array}$ & $\begin{array}{l}\text { The lack of mechanisms } \\
\text { to deal with the } \\
\text { resistance of bus line } \\
\text { companies raises judicial } \\
\text { vetoes and political } \\
\text { pressure against the } \\
\text { subway project. }\end{array}$ & $\begin{array}{l}\text { The resistance made by } \\
\text { bus line companies is } \\
\text { overcome with the } \\
\text { metropolitan } \\
\text { arrangement created, } \\
\text { forcing the municipal } \\
\text { governments to integrate } \\
\text { the bus lines into the } \\
\text { subway. }\end{array}$ \\
\hline
\end{tabular}

Source: Compiled by authors.

\subsubsection{Relations with civil society}

Relations with civil society was a variable that also oscillated between the three phases of the project, in order to condition variations in the construction of political capacities for the implementation of subway infrastructure. 
With regard to phase 1 of the project, the institutional arrangement designed for the implementation of the Salvador subway does not seem to have considered civil society participation as a priority.

As highlighted in one interview, in this period "the subway was a black box," so there was little porosity of the project for the scrutiny of civil society. The high difficulty in collecting documentary data about this phase indicates a low transparency of the institutional arrangement of this period. The main documentary sources available refer to reports produced by TCU and CBTU, in contrast to the difficulties faced during the present research, to have access to documents from CTS and other Salvador city bodies about the subway project. Nor is there evidence, among the scarce data collected, that any participatory process had been carried out by the city of Salvador to discuss the subway project with the population. There is only evidence that the Salvador City Council had taken the lead in opening spaces for discussion of the project with the population through public hearings, as delays in construction work and the delivery schedule of the subway began to be noted.

As pointed out by the TCU since phase 1, indications of irregularities in bidding processes and works $\backslash$ contracts were responsible for gradually affecting the public image of the Salvador subway system. This scenario would intensify over time, reaching its peak in phase 2 , when the project received the derogatory nickname "short pants subway", in reference to the project's shortening by half. By the end of phase 2, repeated delays, readjustments and stoppages, indications of irregularities by the TCU, and suspicions of corruption were circulated by the media - including nationwide - to gradually undermine the credibility of the work before public opinion. Therefore, the Salvador subway project concluded phase 2 of the institutional arrangement with its severely compromised public reputation. Entering phase 3, it can be inferred that there were improvements regarding the inclusion and mobilization of civil society in the Salvador subway project, as already pointed out by Abers (2018). In this case, the PMI again seems to have stood out as an instrument for encouraging social participation and transparency of decision-making processes for reformulating the subway project. In addition, at this stage public hearings were held openly to civil society and in coordination with the municipal legislature. Despite these improvements, the analysis of the interviews with non-state actors suggests that, nevertheless, the dimension of relations with civil society was not well developed 
by the institutional arrangement of the Salvador subway implementation in any of the three phases.

Table 7 - Political capacities to relations with civil society

\begin{tabular}{|c|c|c|c|}
\hline & $\begin{array}{c}\text { Phase 1 } \\
(1997-2005)\end{array}$ & $\begin{array}{c}\text { Phase } 2 \\
(2005-2012)\end{array}$ & $\begin{array}{c}\text { Phase } 3 \\
(2012-2014)\end{array}$ \\
\hline $\begin{array}{l}\text { Relations } \\
\text { with civil } \\
\text { society }\end{array}$ & $\begin{array}{l}\text { - Lack of transparency of } \\
\text { the institutional } \\
\text { arrangement. } \\
\text { - The project (including } \\
\text { its public procurements) } \\
\text { is not subject to } \\
\text { instruments of social } \\
\text { participation. }\end{array}$ & $\begin{array}{l}\text { - Investigations show } \\
\text { evidence of irregularities and } \\
\text { corruption within the } \\
\text { bidding process of public } \\
\text { procurements. }\end{array}$ & $\begin{array}{l}\text { - Unsolicited proposal } \\
\text { procedure (PMI). } \\
\text { - Public hearing. } \\
\text { - Public consultation. }\end{array}$ \\
\hline Outputs & $\begin{array}{l}\text { The lack of porosity } \\
\text { towards civil society } \\
\text { reduces effectiveness of } \\
\text { social control of the } \\
\text { project. }\end{array}$ & $\begin{array}{l}\text { The public reputation of the } \\
\text { project decreases due to the } \\
\text { evidence of corruption. The } \\
\text { project faces severe criticism } \\
\text { from the media and public } \\
\text { opinion. }\end{array}$ & $\begin{array}{l}\text { The use of instruments to } \\
\text { involve civil society } \\
\text { during the remodeling of } \\
\text { the project increases the } \\
\text { legitimacy of the project } \\
\text { and reduces later vetoes. }\end{array}$ \\
\hline
\end{tabular}

Source: Compiled by authors.

\subsubsection{Relations with international organizations}

Relations with international organizations was a variable that also suffered fluctuations between the three phases of the project, in order to condition variations in the construction of political capacities for implementation of the subway infrastructure.

In phase 1 of the project, relations with international bodies were concentrated mainly on relations with the IBRD for the lending of funds through the federal government. In this first phase, relations with this financial institution made possible not only resources, but also international technical and political support for the project. Although the institution also has its own interests, it can be inferred from the analysis of the data that IBRD's participation in the arrangement made possible the presence of a non-state actor that balanced, to some extent, the interests of the three federative spheres involved.

However, relations with the IBRD also created obstacles to building capacity for the implementation of the subway, as it forced CTS to adopt its financial institution's contracting rules - often contradictory to national legislation - which was repudiated by 
the TCU. In this way, while relations with IBRD provided financial resources and technical and political support, on the other hand, it attracted the mandatory bidding rules and contracts adopted by the bank in order to trigger disagreements with TCU.

In any case, by moving to phase 2 , the IBRD ceased to participate in the institutional arrangement of the Salvador subway project, and the federal government assumed all the values formerly held by this bank. In addition, it is worth keeping in mind that the inclusion of this project in the PPI was made possible by an agreement signed between the federal government and the IMF to remove priority infrastructure projects from accounting for fiscal adjustment targets, providing the federal administration with fiscal space to subsidize these projects. Therefore, although indirectly, phase 2 was also marked by strong relations with international organizations, notably the IMF, whose negotiations allowed the deduction of resources invested in the PPI from the federal government's primary surplus target (MACHADO, 2013).

In contrast, with the announcement of Brazil as the host country of the FIFA Soccer World Cup, relations with this organization appear to have had an indirect impact on the project. Salvador, as a host city of the world football event, would have to have provided alternatives for urban minimum passenger mobility that meet FIFA standards. Based on the analysis of the interviews, it is possible to state that relations with FIFA, although not made directly by the organizations in charge of the subway project, were responsible for boosting the efforts of the federal actors (CBTU and Ministry of Cities) towards the rapid completion of the implementation works. It is noteworthy that Brazil was officially chosen in 2007 to host the 2014 World Cup and that in 2009 Salvador was elected one of the cities that would host matches. In summary, the federal government's relations with FIFA were a significant element in the recentralization of the subway project on the federal government's agenda, especially in the period after the transfer of the suburban train system to the administration of the city of Salvador. This situation seems to have persisted and perhaps even intensified in phase 3 of the project as the days of this world sporting event approached. 
Table 8 - Political capacities to relations with international organizations

\begin{tabular}{|c|c|c|c|}
\hline & $\begin{array}{c}\text { Phase 1 } \\
(1997-2005)\end{array}$ & $\begin{array}{c}\text { Phase } 2 \\
(2005-2012)\end{array}$ & $\begin{array}{c}\text { Phase } 3 \\
(2012-2014)\end{array}$ \\
\hline $\begin{array}{l}\text { Relations } \\
\quad \text { with } \\
\text { international } \\
\text { organizations }\end{array}$ & $\begin{array}{l}\text { - Prominence of IBRD in } \\
\text { the project leadership }\end{array}$ & $\begin{array}{l}\text { - IBRD's exit from the } \\
\text { project in } 2005 \\
\text { - Relations with IMF }\end{array}$ & $\begin{array}{l}\text { - Pressure from FIFA in } \\
\text { favor of the project due to } \\
\text { the } 2014 \text { Soccer World } \\
\text { Cup. }\end{array}$ \\
\hline Outputs & $\begin{array}{l}\text { Relations with IBRD are } \\
\text { significant to the } \\
\text { enabling of the federative } \\
\text { convergence to start the } \\
\text { project. }\end{array}$ & $\begin{array}{l}\text { Without IBRD, the project } \\
\text { faces a lack of leadership } \\
\text { which contributes to slowing } \\
\text { down the works by the } \\
\text { municipal government. } \\
\text { Negotiations with IMF } \\
\text { enables that public } \\
\text { expenditure in infrastructure } \\
\text { is not accounted for in fiscal } \\
\text { targets. }\end{array}$ & $\begin{array}{l}\text { FIFA's pressure enables } \\
\text { more engagement from } \\
\text { federal organizations and } \\
\text { more federal funding to } \\
\text { the project. }\end{array}$ \\
\hline
\end{tabular}

Source: Compiled by authors.

\section{Conclusions}

The main research findings are related to the changes that occurred in the local institutional arrangements once the subway implementation passed to the State of Bahia (2012-2014). In the case studied, institutional changes that contributed to the building of policy capacities were related to changes in arrangements that allowed continuity in the flow of financial resources, integration of activities and exchange of information between bureaucracies and dialogues with the urban infrastructure market.

The institutional arrangement for the implementation of the Salvador subway did not remain unaltered over the 15 years of execution of the works, having been subject to changes regarding (i) the roles assigned, including the involvement of new actors, (ii) the availability of resources and competences, (iii) the development of new public policy instruments and (iv) relations with actors outside the arrangement interested or affected by the implementation of the subway.

In the first phase, the institutional arrangement is characterized by a comanagement model between CBTU and CTS, in which the technical expertise and previous experience of the former were shared with the newly created municipal company. It is by no means insignificant that the city of Salvador did not have any 
previous experience in the implementation or even management of urban railway projects.

In the second phase, the arrangement transformed due to changes in the policies of both the federal and municipal governments. At the federal level, the CBTU succeeded in completing the transfer of suburban urban trains to local government, the main interest of the federal government for the entire railway modernization project. At the municipal level, with an alternation of government and political party at the head of the executive branch, the subway had lost centrality in the government agenda and was not endorsed by the new management. In addition, a suburban train administration and operation allocation requires a reallocation of attention and municipal resources. There was, therefore, a repositioning of political projects (federal and municipal) which, in turn, considered the contours of the institutional arrangement. Previous studies on the implementation of the Salvador subway indicate that the local government was not adequately trained to carry out works (LOTTA \& FAVARETTO, 2016; OLIVIERI, 2016; SANTANA, 2017; GOMIDE et al., 2018).

This scenario seems to have become more critical with the transition from a comanagement model to a model almost entirely driven by municipal power and supported by federal resource transfers. Therefore, studies of Salvador's subway policy suggest that the municipal city and the speed of the State of Bahia in completing the implementation of Salvador's subway may be related to aspects of institutional arrangements that enable greater or less resource mobilization and, consequently, construction policy capacities for the implementation of subway infrastructure.

As has already been pointed out in similar previous studies, the high degree of technical expertise required for implementing organizations (PAULA, 2014; \& PEREIRA, 2017) and isolation from the dynamics of using positions as a tool for building political support, in addition to high financial investments, whether from other levels of government or via private financing mechanisms, represented relevant constraints to the construction of Salvador's subway.

In short, the contingency of politics, especially the modifications of the coalitions in power and their respective government projects, seem to have led to changes in policies that in turn conditioned capacity mobilization (MATUS, 1991; 1994; BICHIR, 2015; LOUREIRO et al., 2018). In in this case study, the political dimension was also a conditioning element of policy capacities, which point to the expediency of analyzing 
policy capacities from a situational perspective, considering the political variables that promote changes in institutional arrangements.

The insertion of private actors into the implementation processes of the case studied does not imply a loss of relevance of state organizations, but only that these bureaucracies may be mobilized to play differentiated roles in these new kinds of arrangements, such as the one formed during phase 3. In particular, the results collected here seem to reinforce the idea that the roles attributed to state-owned companies in such institutional arrangements remained relevant, despite their transformation over time due various political and policy-based reasons (PAULA, 2014).

The relational dimension of the arrangement concerning the Salvador subway project was a determining factor for the construction of (i) capacities focused on internal coordination actions of state actors - of the executive branch and of the same federative level - directly responsible for the policy production, as well as for the activation of (ii) political capacities aimed at mobilizing non-state and state actors not included in that first group, involving them in political processes, in order to foster legitimacy and reduce vetoes (LOUREIRO et al., 2014; PEREIRA, 2014 ; Wu et al., 2015; GOMIDE \& PIRES, 2016; MorTARA, 2017; ABERS, 2018).

We argue that the dimensions of federative relations have been widely developed and decisive for policy building capacities. Federative relations held a decisive role in providing technical and managerial support to local implementation and federal funding to the project. Furthermore, the dimension of horizontal integration also played a decisive role in the case studied, especially regarding the activities of the inter-sectoral group formed during the third phase. The creation of such structure enabled a better flow of information and a faster decision-making process, taking in account the participation of relevant leaderships in this working group.

Concerning relations with private agents, the data collected indicates a strong influence exerted by international organizations, normally playing the role of enabling sources of funding. If, on the one hand, these relationships provide resources for the mobilization of financial capacities, then, in the case studied, they also generated financial dependence of institutional arrangements on the rules of these multilateral financial institutions (verified in phases 1 and 2), which can often cause conflicts with control agencies. Therefore, the results from the case studied may show evidence of mutual 
influence between different relational capacities, considering that relations with international organizations may have undermined relations with control agencies.

Regarding relations with control agencies, phase 1 and, mainly, phase 2 were marked by intense conflicts between municipal bureaucracies, federal bureaucracies and control bodies, which may have been partially provoked by the inability of institutional arrangement to involve these actors during policy implementation. However, this scenario changed during the third phase, in which control agencies did not represent such a source of vetoes to the policy but, instead, even played a role in the enforcement of the metropolitan agreements entered into between the State of Bahia and municipal governments.

Nevertheless, the 2012-2014 arrangement was not completely inclusive. Despite all these advances, the arrangement seems not to have taken in account the territorial dimension. The analysis of the data did not reveal any structures, instruments or processes that indicate the processing of territory variables. Some interviews point out that this is due to the fact that most of the subway track is not underground and that it is located on public land where there used to be urban infrastructure. For this same reason, some interviewees point out that the environmental and cultural heritage impact was minimal. This may perhaps explain why environmental licensing and asset protection agencies rarely appear on interviews and official documents.

In addition, the data analysis indicated that the arrangement did not provide mechanisms to articulate companies providing water, sewage, electricity and gas services. We argue that these stakeholders could have been better integrated into the project, since these services are provided at the state level (water, sewage, electricity and gas) and because the subway presents high impact in these urban infrastructures.

Moreover, the social participation dimension was also not given prominence in the arrangement analyzed, since it was articulated only by public audiences, an instrument which is often criticized for its inefficacy.

Results of this research may contribute to a better understanding of how institutional arrangements impact the construction of state capacities for policies. The case studied showed that depending on the design of the arrangement, relevant actors may be involved or not in the policy implementation, including those that could play a role of veto. Furthermore, the conclusions drawn from this case study allow us to advance in the design of institutional arrangements for urban infrastructure policies, especially in the 
coordination of state actors and the mobilization of non-state actors. The case analyses have shown that an institutional arrangement involving bureaucracies and leaderships (from different federative levels), control agencies and private actors may enhance the formation of relational capacities towards the promotion of legitimacy in the policy implementation. Sharing the policy process with other relevant stakeholders through the relations enabled by the institutional arrangement did not undermine the state autonomy, but instead enabled the mobilization of non-state resources in order to increase state agency within the policy.

\section{References}

ABERS, R. N. 2018. Conflitos, mobilizações e participação institucionalizada: A relação entre a sociedade civil e a construção de grandes obras de infraestrutura in Governança da Política de Infraestrutura: condicionantes institucionais ao investimento, Alexandre de Ávila Gomide e Ana Karine Pereira (ed.), Rio de Janeiro: Ipea.

BICHIR, R. M. (2015). Capacidades estatais para a implementação de programas de transferência de renda: Os casos de Brasil, Argentina e África do Sul. (Texto para discussão n. 2032) Instituto de Pesquisa Econômica Aplicada - IPEA. Rio de Janeiro: Ipea.

CINGOLANI, L. (2013). The state of State capacity: a review of concepts, evidence and measures. (Working Paper Series on Institutions and Economic Growth, IPD WP13).

ENAP. (2018). Capacidades Estatais para produção de políticas públicas: resultados do survey sobre o serviço civil no Brasil, 2018. Available in: https://www.enap.gov.br/index.php/pt/pesquisas/capacidades-estatais

Evans, P. B. (1995). 1944. Embedded autonomy: States and industrial transformation. Princeton: Princeton University Press.

Evans, P., RueschmeYeR, D., \& SkOCPOL, T. (1985). On the road toward a more adequate understanding of the State. In: EvANS, P.; RUESCHMEYER, D.; \& SKOCPOL, T. (org.). Bringing the state back in. Cambridge University Press, pp. 346-366.

FIANI, R. (2013). Arranjos institucionais e desenvolvimento: O papel da coordenação em estruturas híbridas. (Texto para discussão n. 1815), Instituto de Pesquisa Econômica Aplicada: Ipea, Rio de Janeiro: Ipea.

GEDDES, B. (1994). Politician's dilemma: Building State capacity in Latin America. Berkeley: University of California Press.

Gomide, A.; Pereira, A. K.; Pompermayer, F. M.; \& Cunha, B. Q. (2018). Condicionantes institucionais à execução do investimento em infraestrutura: achados e recomendações in Gomide, A. Pereira, A. K. (ed.), Governança da Política de Infraestrutura: Condicionantes institucionais ao investimento. Rio de Janeiro, Ipea, pp. 415-444. 
GOMIDE, A. \& PIRES, R. (2014). Capacidades estatais e democracia: a abordagem dos arranjos institucionais para análise de políticas públicas in Capacidades estatais e democracia: Arranjos institucionais de políticas públicas. PIRES, R.C. R. e GOMIDE, A.A. Ipea, Brasília.

(2016). Governança e capacidades estatais: uma análise comparativa de programas federais. Revista de Sociologia e Política. vol. 24, n. 58, p. 121-143, junho.

Gomide, A. A. \& PereirA, A. K. (2018) Capacidades estatais para políticas de infraestrutura no Brasil contemporâneo. Revista de Administração Pública, Rio de Janeiro, v 52, N. 5, p-935-955, SET. 2018 1982-3134. DISPONÍVEL EM: <HTTP://BIBLIOTECADIGITAL.FGV.BR/OJS/INDEX.PHP/RAP/ARTICLE/VIEW/76976/73759>. ACESSO EM: 14 JUN. 2020.

GRINDLE, M. S. (1996). Challenging the State: Crisis and innovation in Latin America and Africa. New York and Cambridge, Cambridge University Press.

. (2007). GoING LoCAL: DECENTRALIZATION, DEMOCRATIZATION, AND THE PROMISE OF GOOD GOVERNANCE. PRINCETON UNIVERSITY PRESS. INSTITUTO DE PESQUISA ECONÔMICA APLICADA. (2010). Infraestrutura social e urbana no Brasil: Subsídios para uma agenda de pesquisa e formulação de políticas públicas, Livro 6 - Vol. 2, IPEA: Brasília, pp. 19-43.

LiMA, Victor Bastos. (2019). Arranjos institucionais e capacidades estatais para implantação de infraestrutura metroviária: nos trilhos do metrô de Salvador. 2019. Dissertação (Mestrado em Análise de Políticas Públicas) - Escola de Artes, Ciências e Humanidades, Universidade de São Paulo, São Paulo. doi:10.11606/D.100.2019.tde-19062019-163309.

LiNDVALL, J. \& TEORELL, J. (2016). State capacity as power: A conceptual framework. (STANCE Working Paper Series; Vol. 2016, No. 1). Lund: Department of Political Science, Lund University.

LotTA, G. S. \& FAVARETO, A. (2016). Desafios da integração nos novos arranjos institucionais de políticas públicas no Brasil. Revista de Sociologia e Política (Online), v. 24, p. 49-65.

LotTA, G. S. \& FAVARETo, A. S. (2018). Os arranjos institucionais dos investimentos em infraestrutura no Brasil: Uma análise sobre seis grandes projetos do Programa de Aceleração de Crescimento. In: GOMIDE, A. \& PEREIRA, A. K. (ed.), Governança da Política de Infraestrutura: Condicionantes institucionais ao investimento. Rio de Janeiro, Ipea, pp. 237-264.

LotTA, G. S. \& VAZ, J. C. (2015). Arranjos Institucionais de Políticas Públicas: aprendizados a partir de casos do Brasil. Revista do Serviço Público, v. 66, p. 171-194.

LOUREIRO, M. R.; TEIXEIRA, M. A. C.; \& FERREIRA, A. M. (2014). Desenvolvendo capacidades estatais: Conflitos e articulação de interesses no Projeto de Integração do Rio São Francisco. Revista Desenvolvimento em Questão, Ano 1, n. 12, n. 28 out./dez..

LOUREIRO, M.; MACARIO, V.; \& GUERRA, P. H. (2015). Legitimidade e efetividade em arranjos institucionais de políticas públicas: O Programa Minha Casa Minha Vida. Rev. Adm. Pública, Rio de Janeiro, v. 49, n. 6, p. 1531-1554, dez.

LOUREIRO, M; SILVA, F., ARANHA, A., CALABREZ, F. Building policy capacity: economic and social policies in Brazil (1988/2016). Paper Presented at the International Workshops on Public Policy, International Public Policy Association (IPPA), Pittsburgh, PA: June 2018. 
MACHADO, R. A. (2013). Políticas de infraestrutura econômica logística e arranjos de coordenação na administração pública federal brasileira no Governo Lula. Revista Eletrônica de Ciência Política - recp, v. 4, p. 11-32.

MATUS, C. (1991). O plano como aposta. São Paulo em perspectiva, outubro-dezembro, pp. 2842.

(1994). Adios, señor presidente: Gobernantes governados. 3a ed. Fondo Editorial Altadir, Venezuela.

MigDAL, J. (1988). Strong societies and weak states: State-Society relations and state capabilities in the Third World, Princeton, New Jersey: Princeton University Press.

Migdal, J. (2001). State in society: Studying how states and societies transform and constitute one another. Cambridge University Press.

MortarA, A. F. (2017). Construção de capacidades estatais: um estudo do Programa Cisternas. 2017. Dissertação (Mestrado em Administração Pública e Governo) - Escola de Administração de Empresas de São Paulo, Fundação Getúlio Vargas, São Paulo.

OLIVIERI, R. (2016). A atuação dos controles interno e externo ao Executivo como condicionante da Execução de Investimentos em Infraestrutura no Brasil (Texto para discussão n. 2252), Instituto de Pesquisa Econômica Aplicada: Ipea, Rio de Janeiro: Ipea.

PAINTER, M. \& PIERRE, J. (2005). Unpacking policy capacity: Issues and themes. In Challenges to State Policy Capacity. New York: Palgrave Macmillan, p. 1-18.

PAUla, P. C. B. (2014). As parcerias público-privadas de metrô em São Paulo: as empresas estatais e o aprendizado institucional no financiamento da infraestrutura de serviços públicos no Brasil. 2014. Dissertação (Mestrado em Direito Econômico e Financeiro) - Faculdade de Direito, Universidade de São Paulo, São Paulo. doi:10.11606/D.2.2017.tde-14122016-102815. Acesso em: 2018-11-01.

PÊGO, B, ROMA, J.C. FERES, J.G. SCHMIDT, L. (2018) O licenciamento ambiental como condicionante à execução de obras de infraestrutura in Governança da Política de Infraestrutura: condicionantes institucionais ao investimento, Alexandre de Ávila Gomide e Ana Karine Pereira (ed.), Rio de Janeiro: Ipea, pp. 319-348.

PEREIRA, A. K. (2014). A construção de capacidade estatal por redes transversais: o caso de Belo Monte. 2014. 264 f., il. Tese (Doutorado em Ciência Política) —Universidade de Brasília, Brasília.

PeREIRA, D. C. A. (2017). Relações público-privadas no Metrô de São Paulo. 2016. Dissertação (Mestrado em Ciência Política) - Faculdade de Filosofia, Letras e Ciências Humanas, Universidade de São Paulo, São Paulo. doi:10.11606/D.8.2017.tde- 14062017-090352. Acesso em: 2018-11-01.

QueIRÓZ, L. N. (2001). Metrô de Salvador: Um novo modelo de concessão de serviços de transporte ferroviário urbano. Revista dos Transportes Públicos, ANTP, Ano 23, $2^{\circ}$ semestre.

SANTANA, S. (2017). Condicionantes institucionais à execução do investimento em infraestrutura no Brasil: Sistema Metroviário de Salvador e Lauro de Freitas. Relatório de Pesquisa, Instituto de Pesquisa Econômica Aplicada (IPEA), Brasília.

SKocPol, T. (1979). States and Social Revolutions: a comparative analysis of France, Russia and China. Cambridge University Press. 
SKOCPOL, T. (1985). Bringing the State back in: Strategies of analysis in current research. In: Evans, P.; RueschMEYER, D.; \& SKOCPOL, T. (org.). Bringing the state back in. Cambridge University Press pp. 3-37.

SKOCPOL, T. \& FINEGOLD, K. (1982). State capacity and economic intervention in the early new deal. Political Science Quaterly, Vol. 97, No. 02, p. 255-278, Summer.

SOIFER, H. D. (2012). Measuring state capacity in contemporary Latin America. Rev. cienc. polit. (Santiago), Santiago, v. 32, n. 3, p. 585-598.

SouZA, Celina. (2017). Modernização do Estado e construção de capacidade burocrática para a implementação de políticas federalizadas. Rev. Adm. Pública, Rio de Janeiro, v. 51, n. 1, p. 27-45, Feb.. Available from

<http://www.scielo.br/scielo.php?script=sci_arttext\&pid=S0034- 76122017000100027\&lng =en\&nrm=iso $>$.access on01 Nov. 2018. http://dx.doi.org/10.1590/0034-7612150933.

TILly, C. (1975). Reflections on the history of European State-making in the formation of national states in Western Europe. Princeton, New Jersey, Princeton University Press.

Wu, X.; Ramesh, M.; \& Howlett, M. (2015). Policy capacity: A conceptual framework for understanding policy competences and capabilities. Policy and Society, v. 34, p. 165- 171.

\section{Victor Bastos Lima \\ iD https://orcid.org/0000-0002-3861-5436}

Legal advisor of the Municipality of São Paulo. Researcher in the Study Group on Technology and Innovation in Public Management (GETIP), from the University of São Paulo (USP). Research assistant at the School National Public Administration (ENAP) by the Cátedras Brasil program between 2018 and 2019. Master in Public Policy Management from the University of São Paulo (USP). Graduated in law from the University of São Paulo (USP).

E-mail:viclima@gmail.com

\section{José Carlos Vaz}

(iD) https://orcid.org/0000-0001-5216-9279

Professor at the University of São Paulo in undergraduate and graduate courses in Public Policy Management. Vice-president of the Administrative Council of Pólis Institute. Coordinator of Study Group on Technology and Innovation in Public Management (GETIP). Graduated in Business Administration from University of São Paulo in 1986, Master in Public Administration from Getúlio Vargas Foundation (FGV-SP) in 1995 and PhD in Business Administration Information Systems from Getúlio Vargas Foundation (FGV-SP) in 2003.

E-mail:vaz@usp.br 